\title{
MULTI-CRITERIA DECISION-MAKING METHODS FOR SUPPLIER SELECTION: A LITERATURE REVIEW
}

\author{
A. Yıldız ${ }^{1 *}$ \& A.Y. Yayla ${ }^{2}$ \\ ${ }^{1}$ Automotive Engineering Department, Technology Faculty \\ Amasya University \\ Amasya, Turkey \\ aytac.yildiz@amasya.edu.tr \\ ${ }^{2}$ Mechanical Engineering Department \\ Marmara University \\ Göztepe, Istanbul, Turkey \\ yayla@marmara.edu.tr
}

\begin{abstract}
A firm's multi-criteria decision-making (MCDM) process is important because of its need to select and work with various suppliers. The process identifies the problems associated with selecting the supplier, , determining convenient criteria, expressing interactions clearly, and usage. These are all suitable methods for finding a solution to these MCDM problems.

Considering more than one criterion (and even the sub-criteria of these criteria) during supplier selection makes the selection uncertain. Conventional methods cannot generate a realistic solution to the problem. Using MCDM methods considerably simplifies solving the problem, and enables decision-makers to make better decisions. In this study, a literature review was performed on MCDM methods used between 2001 and 2014 for the supplier selection problem. MCDM methods used in supplier selection are categorised into three main methods, and a summary table of the reviewed studies is presented.
\end{abstract}

\section{OPSOMMING}

' $n$ Firma se multi-maatstaf besluitnemingsproses is belangrik as gevolg van die behoefte om verskeie verskaffers te kies en dan mee saam te werk. Die proses identifiseer die probleme geassosieer met die kies van die verskaffer, die bepaling van gerieflike kriteria, en wat die duidelike uitdruk van interaksies en die gebruik daarvan, insluit. Hierdie is almal gepaste metodes vir die vind van ' $n$ oplossing tot hierdie multi-maatstaf besluitnemingsproses probleme.

Die oorweging van meer as een maatstaf (en selfs die sub-maatstawwe van hierdie maatstaf) tydens verskaffer seleksie maak die seleksie onseker. Tradisionele metodes kan nie ' $n$ realistiese oplossing tot die probleem genereer nie. Deur van multi-maatstaf besluitnemingsprosesmetodes gerbuik te maak word die oplos van die probleem aansienlik vereenvoudig en dit stel besluitnemers in staat om die beter besluite te neem. ' $n$ Literatuurstudie is gedoen op multi-maatstaf besluitnemingsprosesmetodes gebruik vir die verskaffer seleksie probleem van 2001 tot 2014. Die metodes word in drie afdelings verdeel en ' $n$ opsommende tabel van die studies word voorgehou.

Corresponding author 
Partners of a supply chain are the critical determinants of supply chain behaviour. In this chain, the selection of the partner or the sustainability of partnership is very important for constituting and continuing the supply chain [1].

In today's competitive environment, the decision about supplier selection is very important to the success of production management [2]. Where firms experience intensive competition, working with reliable suppliers is crucial. For that reason, firms seek to work with suppliers who can render service at the required quality level, are suitable in terms of cost, and are flexible about changes in demand. Due to the variety and abundance of expectations of sister companies that work with the suppliers, the problems related to the selection of suppliers are among the complexities frequently encountered by enterprises. Supplier selection is among the most familiar multi-criteria decision-making (MCDM) problems [3]. MCDM methods have a very broad area of use for arranging a series of available alternatives, in terms of multiple criteria. MCDM is a process aimed at finding the best alternative among all of the suitable alternatives. In almost all of the problems, the abundance of criteria for the comparison of alternatives has become widespread. In other words, decision-makers seek to solve the many problems raised by MCDM [4].

Multi-objective decision-making methods are analytical methods. These enable the simultaneous assessment of many measurable and non-measurable strategic and operational factors, and also include many people in the decision-making process. The use of these methods in the decision-making process supports managers with assessing various alternatives, thus enabling a more effective use of their enterprise's resources [5].

In this study, 91 studies that were performed between 2001 and 2014 on the multi-criteria supplier selection were reviewed in order to determine the criteria used for the selection of suppliers and methods. Sector-based distribution of the reviewed papers is presented in Figure 1.

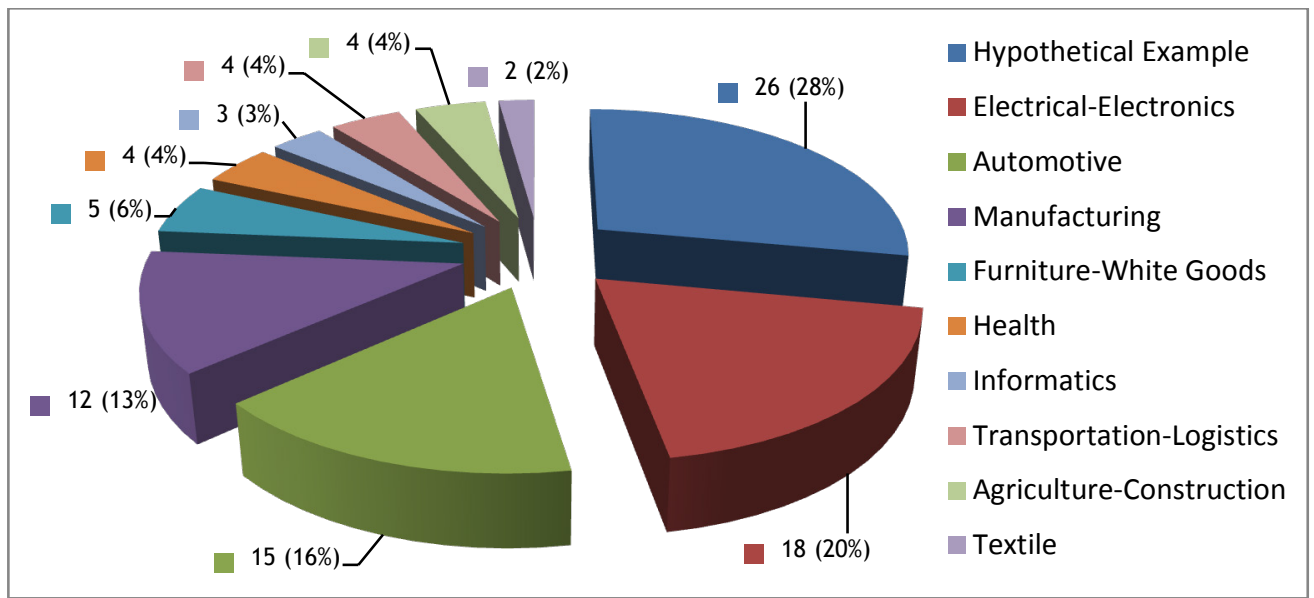

Figure 1: Sector-based distribution of the reviewed papers (see online for colour version)

From Figure 1, it can be noted that 28 per cent of the supplier selection studies presented in the reviewed literature involved hypothetical examples, 20 per cent were from the electrical-electronics sector, 16 per cent from the automotive sector, and 13 per cent from the manufacturing sector. Thus it was determined that supplier selection studies of multicriteria supplier selection were most often done in the electrical-electronics and automotive sectors. Since the products of these two sectors generally consisted of many components, the selection of the suppliers with whom they should have been in cooperation to provide these components was very important for the producers in these sectors. 
The methods that were used in the reviewed papers are summarised under the following three main sections: individual, hybrid, and hybrid fuzzy methods.

\section{INDIVIDUAL METHODS}

In this section, a detailed literature review is presented on individual MCDM methods that were used from 2001 to 2014 for the supplier selection problem. The reviewed papers are categorised into groups on the basis of the individual methods that were used for the different studies presented in the papers. These individual methods are outlined in the following 12 subsections.

\subsection{Analytical hierarchy process (AHP)}

Muralidharan et al. [6] considered group decisions during supplier selection. Suppliers were assessed individually in the group through the AHP method, and the results obtained determined the confidence intervals of each supplier. Suppliers were assessed by ten decision-makers on the basis of their quality, technical activities, and delivery criteria. Muralidharan et al. argued that suppliers should be assessed periodically in case long-term relations are established with the suppliers and they become unmotivated as a result. Therefore, the performances of suppliers were re-assessed and then compared with previous performances at the end of certain periods. Chan [7] used AHP and an interactive selection model to ease the decision-making procedures during supplier selection. In Chan's study, AHP was only used to generate the total scores of alternative suppliers; these would depend on the rates of relative significance. Chan and Chan [8] used AHP for supplier selection, using criteria that consisted of six basic assessment criteria and 26 other criteria whose relative significance was calculated according to the rates of the customer needs. Liu and Hai [9] used the AHP method for supplier selection in the furniture white goods sector. Depending on the criteria and sub-criteria selected by sixty managers, weights and scores were calculated for the suppliers. Hou and Su [10] used the AHP method for webbased supplier selection in the electrical-electronics sector. In this study, five alternative suppliers were arranged according to their priority weights. Chan et al.'s [11] study, which also used the AHP method for solving the supplier selection problem, included 14 criteria for supplier selection. With the help of a sensitivity analysis that was conducted at the end of the study, Chan et al. changed the relative significance rates of each criterion and examined the answers of the alternatives. Asamoah et al. [12] applied the AHP method for supplier evaluation and selection in a pharmaceutical manufacturing firm in Ghana. Bruno et al. [13] used the AHP method to select the best supplier in the Italian railway industry.

\subsection{Analytical network process (ANP)}

Depending on organisational factors and strategic performance measures, Sarkis and Talluri [14] used the ANP method for the assessment and selection of the best supplier. Bayazit [15] used the method to select the best supplier in a hypothetical example. Gencer and Gurpinar [16] also used the method in their study of supplier selection in the electricalelectronics sector. In their study, three alternative suppliers were assessed according to 45 sub-criteria under three main criteria, and the best supplier was selected at the end of the study. Liao et al. [17] used the method to select the optimal programme supplier for Taiwanese TV channels. Some of the selection criteria that were used in their application included performance (quality, launch at correct timing), feedback (reputation, rate, finance), interaction (relation, behaviour, communication), and production (creativity, price, time). At the end of their study, four suppliers were arranged according to their total weights.

\subsection{Data envelopment analysis (DEA)}

Narasimhan et al. [18] used the DEA method to assess alternative suppliers for an international company in the electrical-electronic sector. Mahdiloo et al. [19] also used DEA in their study of supplier selection in order to classify suppliers according to their efficiency scores. Dobos and Vörösmarty [20] developed a supplier selection method based on DEA. 


\subsection{Grey Relational Analysis (GRA)}

Li et al. [21] used the GRA method for supplier selection. Four decision-makers assessed the supplier selection criteria, which included product quality, service, distribution, and price. $\mathrm{Li}$ et al. then analysed seven suppliers and chose the best supplier by considering relevant factors.

\subsection{Artificial neural networks (ANN)}

Florez-Lopez [22] used the ANN-based self-organising feature map (SOFM) approach in order to measure both the qualitative and the quantitative variables in supplier selection in a hypothetical example. At the end of the study, which assessed five suppliers, suppliers were divided into various sections on a map. In their study, Aksoy and Ozturk [23] performed the ANN-based supplier selection and assessment on data obtained from an automotive company; at the end of the study, suppliers were divided into three classes. Golmohammadi [24] applied the method to select the best supplier among 31 suppliers for eight products of a firm in the automotive sector. First a neural network model was designed in an attempt to assess the performance of the supplier according to the managers' decisions. Second, the model was re-assessed through the inputs and outputs of the model. Supplier scores were then obtained at the end of the application and a sensitivity analysis was conducted in the final phase of the study.

\subsection{Goal programming (GP)}

Karpak et al. [25] used the goal programming model for supplier selection and assessment; the amount of optimal product order was also determined at the end of their study. Jadidi et al. [26] used a multi-objective optimisation problem (MOOP) for solving supplier selection.

\subsection{Linear programming (LP)}

In their study, Ghodsypour and O'Brien [27] used the mixed-integer non-linear programming (MINLP) model for supplier selection. Talluri [28] used the binary-integer LP method for supplier selection in the health sector. Four models were developed to provide flexibility in supplier selection and to assist the customer in different types of sales. In their study, Talluri and Narasimhan [29] used the max-min approach for supplier selection in the health sector. Six alternative suppliers were assessed according to price, quality, and delivery criteria; the order level of suppliers was also calculated at the end of the study. Hong et al. [30] applied the mixed-integer LP method to supplier selection in the agricultural sector; the number of optimal suppliers and the optimal level of orders were also determined at the end of the study. $\mathrm{Ng}$ [31] used the weighted LP model to maximise the supplier score in the supplier selection problem. Ware et al. [32] developed MINLP to solve the dynamic supplier selection problem.

\subsection{Multi-objective programming (MOP)}

Narasimhan et al. [33] developed an MOP model to indicate the best supplier and the optimal order quantity. They suggested five criteria for supplier selection and derived the relative significance weights of the criteria before the solution of the optimality model. At the end of their study, Narasimhan et al. suggested that AHP could be used for generating the criteria weights. Ozkok and Tiryaki [34] applied the multi-objective linear supplier selection problem with multiple-item (MLSSP-MI) method to supplier selection and assessment for a textile firm in Turkey. Amin and Zhang [35] presented a multi-objective mixed-integer LP model for supplier selection, order allocation, and closed loop network configuration.

\subsection{Simple multi-attribute rating technique (SMART)}

Barla [36] used a SMART-based, five-stage methodology for supplier selection and assessment in a glass-producing firm,based on seven assessment criteria that they identified. At the end of the study, the supplier with the highest score was selected. 


\subsection{Case-based reasoning (CBR)}

Choy et al. [37] applied the CBR method to information-based supplier selection and assessment in the production sector. At the end of their study, they arranged the alternative suppliers according to supplier selection performance.

\subsection{Genetic algorithm (GA)}

Liao and Rittscher [38] used the GA method for the supplier selection problem under stochastic demand quantities and lead time. They solved the supplier selection problem in five situations by comparing the selection criteria in two parts.

\subsection{Technique for order preference by similarity to ideal solutions (TOPSIS)}

Safa et al. [39] used TOPSIS to select the most suitable supplier according to criteria such as price, lead time, performance, and early payment.

From this review of the literature, the proportions of individual methods used for the supplier selection process are presented in Figure 2.

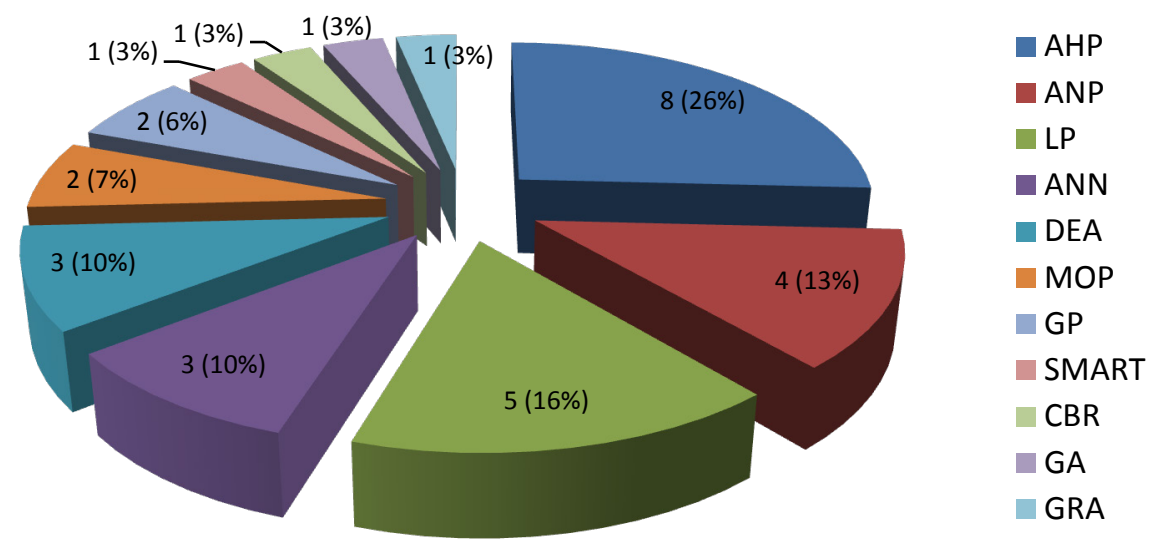

Figure 2: The individual methods used for supplier selection (see online for colour version)

Examining the results of the figure, it is noted that 26 per cent (8) of the individual methods consisted of AHP and 16 per cent (5) consisted of LP.

It was seen from the above results that AHP is frequently used in the individual methods. AHP seems to be a popular approach that attempts to quantify human judgement and opinion that other approaches may not take into account. Moreover, it is an effective statistical method that integrates with different approaches when working out the final choice of suppliers. The method is flexible and easy to understand, and can help decisionmakers to handle risk management problems logically and rationally. The strongest features of AHP are that it gives numerical priorities from the subjective knowledge expressed in the estimates of paired comparison matrices. AHP's strong point lies in its ability to analyse a complex, multi-person, and multi-attribute problem hierarchically, and then to investigate each level of the hierarchy separately, combining the results as the analysis progresses.

\section{HYBRID METHODS}

In this section, a detailed literature review is presented on hybrid MCDM methods that were used from 2001 to 2014 for the supplier selection problem. The reviewed papers are categorised into groups on the basis of the hybrid methods that were used for the different studies presented in the papers. These methods, which are presented in the following three subsections, can be grouped as follows: 


\subsection{Hybrid AHP}

The hybrid AHP-GP approach was used for supplier selection by Percin [40] and Kull and Talluri [41] in the automotive sector, and by Mendoza et al. [42] for a hypothetical example. AHP was used to calculate the assessment criteria, and suppliers were selected by transferring these weights into the GP model. Yang and Chen [43] applied the AHP method to calculate the relative significance weights of qualitative criteria in supplier selection; the supplier with the highest value was then selected as the best supplier by using the weights obtained from the AHP as the coefficients of the GRA model. Ramanathan [44] used DEA to assess suppliers' performance by using the total cost of the ownership and qualitative and quantitative information obtained from the AHP. In that study, the weights that were calculated in AHP were used as the DEA inputs. Sevkli et al. [45] used the AHPDEA approach for supplier selection and assessment. In their study, while AHP was applied to calculate the relative weights of each supplier, DEA was applied to calculate the relative efficiency of each supplier. In their hypothetical supplier selection example, Xia and Wu [46] used the AHP and multi-objective mixed-integer programming (MIP) methods. Huang and Keskar [47] used the AHP-multi-attribute utility theory (MAUT) methods for supplier selection. In their study, while AHP was used to obtain the criteria weights, MAUT was used to establish the useful functions. At the end of that study, useful values were obtained for each supplier.

$\mathrm{Ha}$ and Krishnan [48] used a hybrid approach that consisted of AHP, ANN, and DEA for supplier selection in a firm producing auto components, according to assessment criteria. Kokangul and Susuz [49] used the AHP and non-linear integer programming methods in their study of supplier selection in a large automobile producer. The AHP method was used as an attempt to calculate the weights of suppliers in order to select them. The weights obtained from the AHP method were applied as the coefficients of the objective function in the suggested model, and the order amounts to be received from the suppliers were calculated accordingly. Chamodrakas et al. [50] used the AHP-based fuzzy preference programming (FPP) method to determine the best supplier. In their numerical study, Amid et al. [51] used the AHP-max-min fuzzy programming methods for supplier selection. The AHP method was applied to calculate the criteria weights and select the suppliers; the order quantity to be received from the suppliers was calculated by using the data obtained from the AHP in the max-min fuzzy programming method.

Mafakheri et al. [52] suggested a two-phase multiple-criteria dynamic programming approach to supplier selection and order allocation activities, which are very critical in supply chain management. While the AHP method was used to determine the orders of suppliers in the first phase, it was used to minimise the supplier order level and the costs of total supply chain, and to maximise the functions that are useful for the firm in the second phase of the order allocation model. Chen and Chao [53] applied the AHP model with the consistent fuzzy preference relations (CFPR) method to supplier selection in an electronic company in southern Taiwan. Rajesh and Malliga [54] developed an integrated approach that combined AHP and quality function deployment (QFD) to select suppliers strategically. Chen and Wu [55] applied a modified failure mode and effects analysis (MFMEA) method to select new suppliers from the perspective of supply chain risk, and the AHP method to determine the weight of each criterion and sub-criterion for supplier selection.

\subsection{Hybrid ANP}

Shyur and Shih [56] used a hybrid model for supplier selection in a study that combined the ANP and TOPSIS methods. During the first phase of the model, the required criteria were predetermined for supplier selection and the nominal group technique (NGT) was used to describe the internal dependency between the criteria. The ANP method was applied through the assessment of the criteria predetermined by three decision-makers, and alternative suppliers were arranged by using the criteria weights that were obtained at the end of the TOPSIS method. Finally, the supplier with the highest-ranking order in the closeness coefficient was determined as the best supplier. In a study of supplier selection in a firm that produces notebooks in Taiwan, Wu et al. [57] used the ANP and MIP methods. Criteria weights were calculated as a result of the assessments performed with the ANP 
method, in light of the selection criteria that were predetermined during the first phase of the study. Suppliers were selected by using the weights obtained from the ANP in the MIP method during the second phase. Finally, the order levels to be received from the suppliers were also calculated.

\subsection{Hybrid ANN}

Kuo et al. [58] used a hybrid method that consisted of ANN, ANP, and DEA methods for the selection problem of environmentally-friendly suppliers in an electronic firm in Taiwan. In their study, the results obtained through the use of these three methods and dual uses of these methods were compared.

From this review of the literature, the hybrid methods used in supplier selection are summarised in Figure 3.

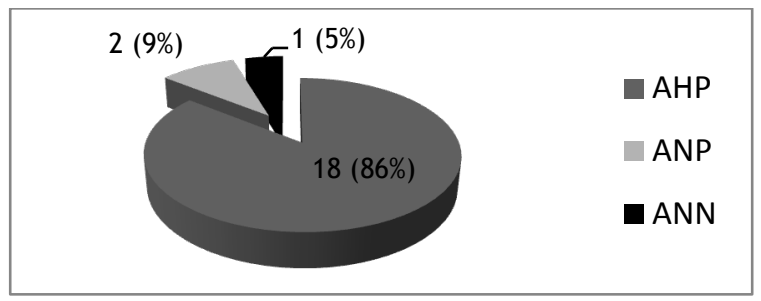

Figure 3: Hybrid methods used for supplier selection

From Figure 3, it is noted that a great majority (86 per cent (18)) of hybrid methods used in supplier selection consisted of AHP.

It can be concluded that AHP is easy to use, has great flexibility and wide applicability, and is logically consistent. It provides an estimate of additive utility weight that best matches the initial information provided by the decision-maker, and it provides a meaningful way to measure and combine tangible and intangible criteria in any decision. It can also be used with other techniques, such as mathematical programming, to take into account not only qualitative and quantitative factors, but also some real-world resource limitations (e.g., processing capacity, quality, and budget) [49]. AHP also has great capacity for handling qualitative and quantitative criteria used in such problems [50].

\section{HYBRID FUZZY METHODS}

In this section, a detailed literature review is presented of hybrid fuzzy methods that were used from 2011 to 2014 for the supplier selection problem. The reviewed papers are categorised into groups on the basis of the hybrid fuzzy methods that were used for the different studies presented in the papers. These methods, which are outlined in the following nine subsections, can be grouped as follows:

\subsection{Fuzzy TOPSIS}

Chen et al. [59] applied the fuzzy TOPSIS method to supplier selection in an advanced technology production firm. Depending on the five predetermined criteria for suppliers, three decision-makers assessed five alternative suppliers. At the end of the study, alternative suppliers were arranged according to their closeness coefficients. Shahanaghi and Yazdian [60] applied the fuzzy TOPSIS method to select the best supplier according to the predetermined criteria, in terms of the purchase of main components from alternative suppliers in an automotive company; the best supplier was selected at the end of the calculations that were performed after the assessment of four alternative suppliers by three decision-makers, according to the predetermined criteria. Buyukozkan and Ersoy [61] used the fuzzy TOPSIS method to select the external source suppliers of a firm operating in the informatics sector in Turkey. Boran et al. [62] used the TOPSIS method combined with the intuitionistic fuzzy set to select the supplier for a key component in the production process of an automotive company. An intuitionistic fuzzy weighted averaging (IFWA) 
operator was used to aggregate the individual opinions of decision-makers in rating the importance of criteria and alternatives. At the end of the study, alternative suppliers were arranged according to their closeness coefficients.

In the study of Wang et al. [63], three suppliers were assessed and arranged by three decision-makers according to four supplier selection criteria, performed according to the fuzzy TOPSIS-based hierarchical TOPSIS method. At the end of the study, it was indicated that this method was more reasonable than other methods, and could be applied to the calculation of weights in future studies or other decision-making areas. Awasthi et al. [64] used the fuzzy TOPSIS method for supplier selection; 12 selection criteria, which were determined in line with expert opinion, were assessed by three expert decision-makers for four alternative suppliers, and then suppliers were arranged according to their closeness index. A sensitivity analysis was conducted at the end of the study. Chen [65] used a twophase method that consisted of DEA and fuzzy TOPSIS methods for supplier selection in the textile sector in Taiwan. Liao and Kao [66] used the fuzzy TOPSIS and GP methods to select material suppliers for the purchase of key components in a firm producing clocks. In their study, a three-member decision-making committee assessed five alternative suppliers who were selected according to the predetermined criteria of supplier selection. In that study, fuzzy TOPSIS and GP were used in combination, and suppliers were arranged according to their closeness index. At the end of the study, the number of products to be received from suppliers was also determined. In a study performed in an automotive production factory that sought to purchase inside and outside mirrors for three automobile models, Jolai et al. [67] used fuzzy TOPSIS and GP methods to select the best supplier and determine the order quantity. Six suppliers chosen by the factory were then assessed by three decision-makers. The best supplier was selected with the fuzzy TOPSIS method and order quantity was determined by using the weights obtained from the fuzzy TOPSIS method combined with the GP method. At the end of the study, a sensitivity analysis determined that the results were consistent. Rouyendegh et al. [68] used a two-phase solution fuzzy TOPSIS method and multi-choice goal programming (MCGP) to select the best supplier. Junior et al. [69] used fuzzy TOPSIS and fuzzy AHP methods to aid the supplier selection decision process in the automotive industry.

\subsection{Fuzzy AHP}

In a study performed in the manufacturing sector, Chan and Kumar [70] used the fuzzy extended AHP method to select the best global supplier for supplying critical components used in the assembling process. Three suppliers, who had been chosen according to the predetermined selection criteria, were assessed in accordance with the whole main/subcriteria; at the end of the study, the best global supplier was selected. Bottani and Rizzi [71] used fuzzy AHP and clustering analysis to select suppliers who enable the production of manufacturing and packaging machines of beverage products in Italy. In their study, while fuzzy AHP was applied to assess and arrange AHP alternatives, clustering analysis was applied to classify the arranged alternatives into convenient clusters; these applications reduced the number of suppliers from 92 to 18. Lee [72] suggested an analytical approach to select suppliers under fuzzy environments, and arranged the alternative suppliers at the end of the study by using the fuzzy AHP method to select suppliers for a firm producing TVs in Taiwan Sen et al. [73] used the fuzzy AHP and max-min approach for the primary selection of suppliers in the electrical-electronic industry in Turkey. While the fuzzy AHP method was used to determine the weights of the selected cost, quality, service, and reliability criteria, the max-min approach was used to describe the efficient supplier cluster according to the weighted criteria and non-parametric statistical test, and to maximise and minimise the supplier performance. The efficient supplier cluster was determined at the end of the study.

Kilincci and Onal [74] applied the fuzzy AHP method to select the best supplier in a firm that produces furniture-white goods in Turkey. Three alternative suppliers were assessed by this method, using the criteria that were obtained from the experience and research of experts in the production planning department. The supplier with the highest priority weight was selected as the best supplier. Khorasani and Bafruei [75] selected the best 
supplier in the health sector of Iran. First, the most important criteria of supplier selection, such as price, quality, service, organisation, and technical issues, were determined through literature research. The best supplier was then selected through the use of fuzzy AHP, and they suggested that this method be used in combination with GP for future studies. Zeydan et al. [76] used fuzzy AHP, fuzzy TOPSIS, and DEA methods in their study of supplier selection and assessment in the automotive sector in Turkey. The fuzzy AHP method was applied to calculate the weights of the determined supplier selection criteria; the weights that were obtained from here were transferred to the fuzzy TOPSIS method, and suppliers were selected and assessed by using the results in the DEA method as an output. Punniyamoorth et al. [77] conducted field research for supplier selection; structural equation modelling (SEM) and fuzzy AHP methods were used on the results obtained from those who responded to this field research. The primary step in the study was to generate hypotheses about the supplier selection criteria, and then the relationships between the SEM and criteria and suppliers were revealed. Finally, suppliers were arranged according to their priority weights with the help of fuzzy AHP. Kannan et al. [78] applied fuzzy AHP, fuzzy TOPSIS, and fuzzy multi-objective linear programming (MOLP) to solve the problem of supplier selection and order allocation for an automobile manufacturing company in Iran. Kar [79] used fuzzy AHP and fuzzy GP for the solution supplier selection problem. Rezaei et al. [80] used fuzzy AHP to evaluate suppliers according to main criteria and sub-criteria.

\subsection{Fuzzy ANP}

Razmi et al. [81] used the fuzzy ANP method for supplier selection. Four alternative suppliers were assessed according to six criteria, and alternative suppliers were arranged with the help of the method applied in the study. A sensitivity analysis was also conducted at the end of the study. Tuzkaya et al. [82] used the fuzzy ANP and fuzzy PROMETHEE methods in their study of supplier selection in the furniture white goods sector. Four alternative suppliers were assessed and arranged with this hybrid model, according to the six predetermined criteria for supplier selection. A sensitivity analysis was also conducted at the end of the study. Onut et al. [83] applied the fuzzy ANP and fuzzy TOPSIS methods to assess suppliers in the electrical-electronics sector in Turkey. Six suppliers were assessed with the fuzzy ANP method according to the predetermined criteria, and the criteria weights were obtained. Alternative suppliers were arranged by using the obtained weights in the fuzzy TOPSIS method, and a sensitivity analysis was conducted. In a hypothetical example of a firm that produces TVs, Wei et al. [84] used the fuzzy ANP method to select the best supplier from among the alternative suppliers. Vinodh et al. [85] used the fuzzy ANP method in their study of supplier selection in the electrical-electronics sector in India. In their study, three alternative suppliers were assessed under five supplier selections, and at the end of the study alternative suppliers were arranged and a sensitivity analysis was conducted. Buyukozkan and Cifci [86] used the fuzzy ANP method for supplier selection in a firm that operates in the furniture white goods sector in Turkey. Five alternative suppliers were assessed according to five criteria for supplier selection, and alternative suppliers were arranged. A sensitivity analysis was also conducted at the end of the study. Lin [87] used an integrated fuzzy ANP and fuzzy MOLP model for supplier evaluation and selection. Dargi et al. [88] used the fuzzy ANP method to evaluate suppliers for semi-assembly parts of an automobile manufacturer in Iran.

\subsection{Fuzzy SMART}

Chou and Chang [89] used the fuzzy SMART approach to the supplier selection problem in a firm operating in the IT sector in Taiwan, according to five qualitative and quantitative criteria. In their study, three alternative suppliers were discussed and five decision-makers made assessments according to the selected criteria. At the end of the study, alternative suppliers were arranged according to their total crisp values, and a sensitivity analysis was conducted. They also suggested in their study that it would be convenient to use the SMART method for supplier selection in future studies.

\subsection{Fuzzy quality function deployment (QFD)}

Bevilacqua et al. [90] suggested a new method that transfers the approach of typical QFD to the house of quality (HOQ) method in supplier selection. They applied this method as 
fuzzy $\mathrm{HOQ}$ for the supplier selection of a firm operating in the automotive sector, and then they re-arranged the alternative suppliers at the end of the study. Amin and Razmi [91] used a fuzzy model that is integrated with the QFD for the selection of suppliers who provide internet services in the informatics sector in Iran. At the end of the study, alternative suppliers were arranged and a sensitivity analysis was conducted.

\subsection{Fuzzy adaptive resonance theory (ART)}

Keskin et al. [92] used the fuzzy ART method for selecting convenient material suppliers who purchase rod and tie-rod components for an automotive production company. A decision-making committee, consisting of a group leader and the quality, purchase, production, and finance departments, determined fifteen selection criteria, and these were assessed for ten alternative suppliers. At the end of the study, the best suppliers were arranged and then grouped into different categories.

\subsection{Fuzzy set theory (FST) and the Dempster Shafer theory of evidence (DST)}

Deng and Chan [93] proposed a MCDM methodology that combines FST and DST in the best supplier selection. First, the proposed method used linguistic items modelled as fuzzy numbers to represents experts' subjective opinions, in addition to crisp numbers to rank the performance of each criterion. At the end of their study, alternative suppliers arranged according to discounting coefficient of their.

\subsection{Logarithmic fuzzy preference programming (LFPP)}

Wang and Chin [94] applied the method of LFPP to select a transportation firm in the transportation logistics sector in Turkey. Suppliers' priority weights were calculated as a result of the assessments, which were performed in light of the three main criteria that had been predetermined.

\subsection{Fuzzy multi-objective programming (MOP)}

Amid et al. [95] used the fuzzy MOP method for supplier selection in a hypothetical example. In their study, cost, quality, service, and capacity were considered as the supplier selection criteria. The study was based on three basic objectives: minimising the net costs, decreasing rejected products, and minimising delivery delays. In order to attain these goals, three different conditions were considered in the study; as a consequence, results were obtained for the goals that were to be attained for these three conditions. NazariShirkouhi et. al [96] used an interactive two-phase fuzzy MOLP model to solve a supplier selection problem with multiple price levels and multiple products.

After reviewing the literature, the hybrid methods used in supplier selection are presented in Figure 4.

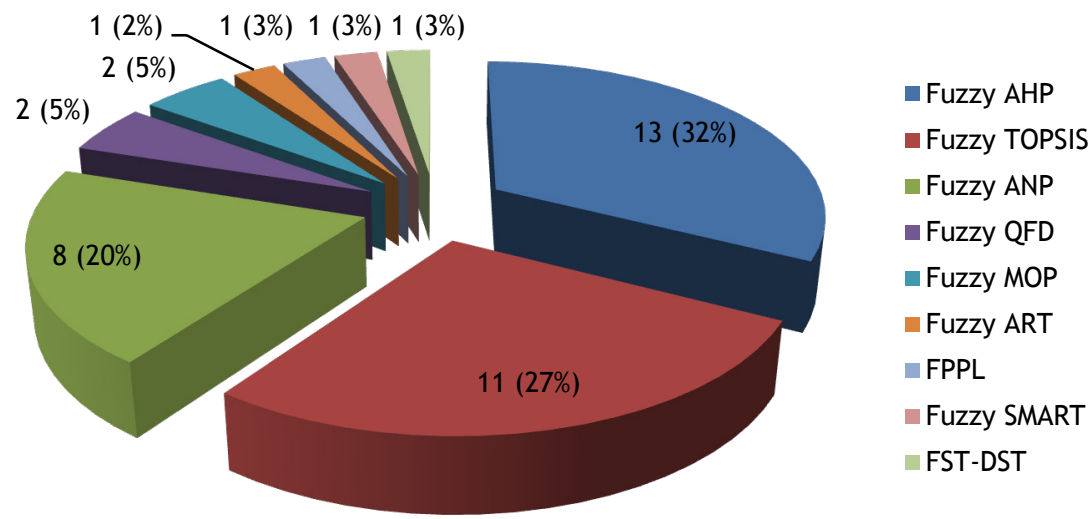

Figure 4: Hybrid fuzzy methods used in supplier selection (see online for colour version) 
From Figure 4, it is noted that fuzzy AHP, fuzzy TOPSIS, and fuzzy ANP are frequently used in the hybrid fuzzy methods, and that the use of hybrid fuzzy methods has become widespread over the last decade.

It is worth highlighting that in fuzzy TOPSIS, attributed values are represented by fuzzy numbers. Using this method, the decision-makers' fuzzy assignments with different rating viewpoints and the trade-offs among different criteria are considered in the aggregation procedure to ensure more accurate decision-making [83].

After reviewing the literature, the sector-based distribution of the methods used in supplier selection is presented in Figure 5.

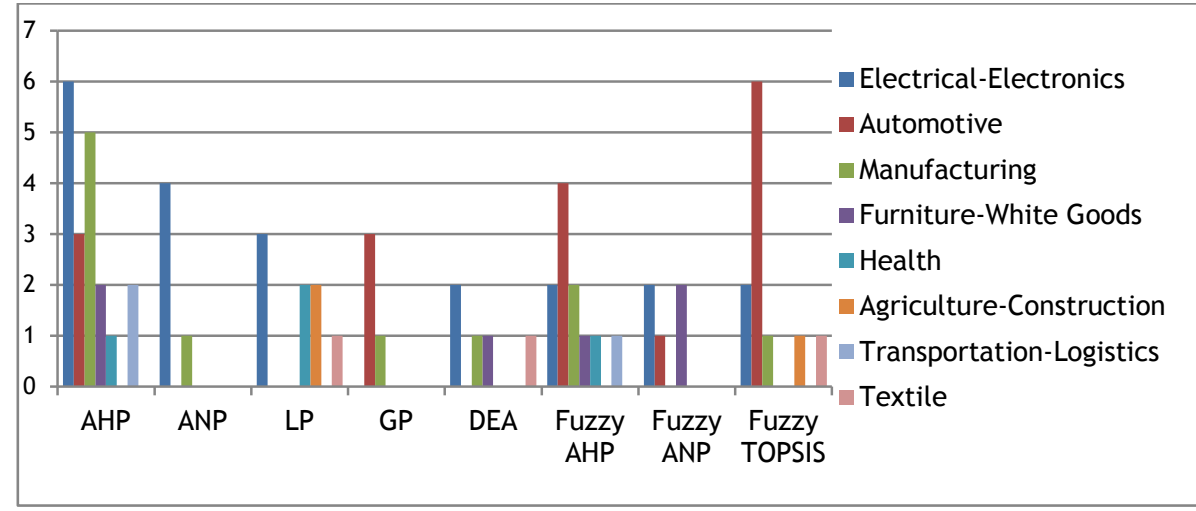

Figure 5: Sector-based distribution of the methods used in supplier selection (see online for colour version)

From Figure 5, it follows that while AHP is mostly used in the electrical-electronics and manufacturing sectors, ANP is mainly used in the electrical-electronics sector, and GP, fuzzy AHP, and fuzzy TOPSIS are often used in the automotive sector.

On the other hand, examining the supplier selection criteria presented in Figure 6, the rates of use are as follows: quality is 22 per cent, delivery is 17 per cent, cost is 15 per cent, and price is 14 per cent.

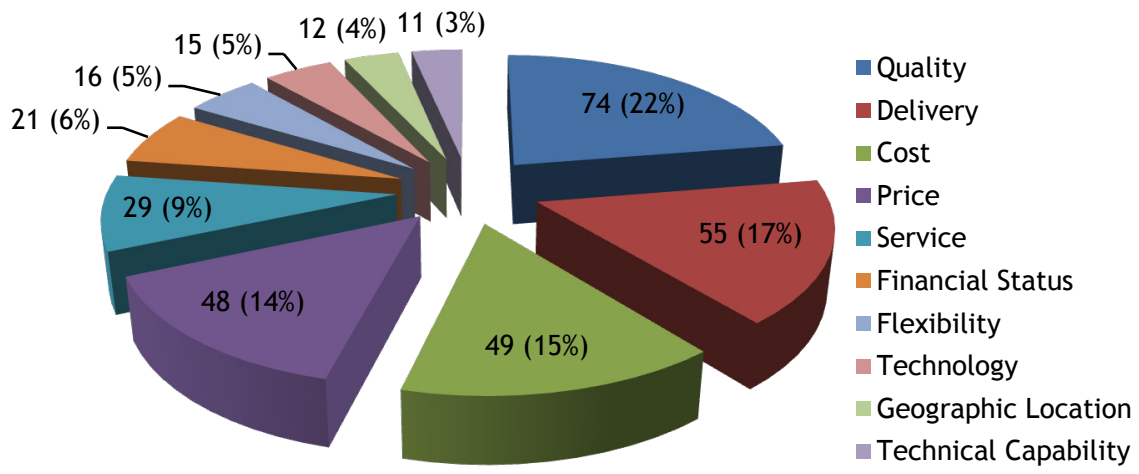

Figure 6: Supplier selection criteria (see online for colour version)

The chronological summary of the literature review addressing MCDM methods used in supplier selection and their sector-based application can be seen in the table presented in the Appendix. 
Together with increasing global competition, enterprises encounter the pressure of reducing their production and material costs in order to sustain competitive advantage. For this reason, supplier selection has become very important. As one of the MCDM problems, supplier selection problems are frequently encountered within supply chain management. Furthermore, the determination of the convenient criteria and methods, and a clear expression of interactions, is very important for solving these problems. Scientific methods should be used in the supplier selection process in order to determine enterprises' preferences accurately. Otherwise, suppliers who do not meet the determined objectives might be selected.

In this study, a literature review was conducted on MCDM methods that were used between 2001 and 2014 for the supplier selection problem. Altogether, 91 studies were examined. The methods that were used for supplier selection were separated into three main groups: individual, hybrid, and hybrid-fuzzy methods.

Examining the resulting tables, AHP is mostly used in the individual and hybrid methods; fuzzy AHP, fuzzy TOPSIS, and fuzzy ANP are mostly used in the hybrid fuzzy methods; and the use of hybrid fuzzy methods has become widespread for the last decade.

Examining the sector-based distribution of the reviewed studies on methods used in supplier selection, it becomes evident that supplier selection studies are predominantly conducted in the electrical-electronics and automotive sectors. Since the products these two sectors produce generally consist of many components, the selection of suppliers with whom they should cooperate to provide these components is very important for the producers in these sectors.

Regarding the distribution of sector-based applications of methods used in supplier selection, it was revealed that AHP was mostly used in the electrical-electronics and manufacturing sector, ANP was used in the electrical-electronics sector, fuzzy AHP was used equally in the electrical-electronics and manufacturing sectors, and GP, fuzzy AHP, and fuzzy TOPSIS were used in the automotive sector.

This study is regarded as an important guide for researchers and performers who will conduct studies of the supplier selection problem, especially in seeking to understand the frequency of the supplier selection criteria and methods being used in supplier selection, whether generally or sector-based.

\section{REFERENCES}

[1] Chen, K.L., Chen, K.S. \& Li, R.K. 2005. Suppliers capability and price analysis chart. International Journal of Production Economics, 98, pp. 315-327.

[2] Weber, C.A., Current, J.D. \& Desai, A. 2000. An optimization approach to determining the number of vendors to employ. Supply Chain Management: An International Journal, 5(2), pp. 9098.

[3] Timmerman, E. 1986. An approach to vendor performance evaluation. Journal of Purchasing and Materials Management, 26(4), pp. 2-8.

[4] Saghafian, S. \& Hejazi, S.R. 2005. Multi-criteria group decision making using a modified fuzzy TOPSIS procedure. International Conference on Computational Intelligence for Modelling, Control and Automation, and International Conference on Intelligent Agents, Web Technologies and Internet Commerce, IEEE.

[5] Narasimhan, R. 1983. An Analytical approach to supplier selection. Journal of Purchasing and Materials Management, 19(4), pp. 27-32.

[6] Muralidharan, C., Anantharaman, N. \& Deshmukh, S.G. 2002. A multi-criteria group decisionmaking model for supplier rating. The Journal of Supply Chain Management, Fall, pp. 2233.

[7] Chan, F.T.S. 2003. Interactive selection model for supplier selection process: An analytical hierarchy process approach. International Journal of Production Research, 41(15), pp. 35493579 . 
[8] Chan, F.T.S. \& Chan, H.K. 2004. Development of the supplier selection model - A case study in the advanced technology industry. Proceedings of the Institution of Mechanical Engineers, Part $B$ - Journal of Engineering Manufacture, 218 (12), pp. 1807-1824.

[9] Liu, F.H.F. \& Hai, H.L. 2005. The voting analytic hierarchy process method for selecting suppliers. International Journal of Production Economics, 97(3), pp. 308-317.

[10] Hou, J. \& Su, D. 2006. Integration of web services technology with business models within the total product design process for supplier selection. Computers in Industry, 57, pp. 797-808.

[11] Chan, F.T.S., Chan, H.K., Ip, R.W.L. \& Lau, H.C.W. 2007. A decision support system for supplier selection in the airline industry. Proceedings of the Institution of Mechanical Engineers, Part $B$ Journal of Engineering Manufacture, 221(4), pp. 741-758.

[12] Asamoah, D., Annan, J. \& Nyarko, S. 2012. AHP approach for supplier evaluation and selection in a pharmaceutical manufacturing firm in Ghana. International Journal of Business and Management, 7(10), pp. 49-62.

[13] Bruno, G., Esposito, E., Genovese, A. \& Passaro, R. 2012. AHP-based approaches for supplier evaluation: Problems and perspectives. Journal of Purchasing and Supply Management, 18(3), pp. 159-172.

[14] Sarkis, J. \& Talluri, S. 2002. A model for strategic supplier selection. The Journal of Supply Chain Management, Winter, pp. 18-28.

[15] Bayazit, 0. 2006. Use of analytic network process in vendor selection decisions. Benchmarking: An International Journal, 13(5), pp. 566-579.

[16] Gencer, C. \& Gurpinar, D. 2007. Analytic network process in supplier selection: A case study in an electronic firm. Applied Mathematical Modelling, 31(11), pp. 2475-2486.

[17] Liao, S.K., Chang, K.L. \& Tseng, T.W. 2010. Optimal selection of program suppliers for TV companies using an analytic network process (ANP) approach. Asia-Pacific Journal of Operational Research, 27(6), pp. 753-767.

[18] Narasimhan, R., Talluri, S. \& Mendez, D. 2001. Supplier evaluation and rationalization via data envelopment analysis: An empirical examination. The Journal of Supply Chain Management, Summer, pp. 28-37.

[19] Mahdiloo, M., Noorizadeh, A. \& Saen, R.F. 2011. A new approach for considering a dual-role factor in supplier selection problem. International Journal of Academic Research, 3(1), pp. 261266.

[20] Dobos, I. \& Vörösmarty, G. 2014. Green supplier selection and evaluation using DEA-type composite indicators. International Journal of Production Economics, 157, pp. 273-278.

[21] Li, G.D., Yamaguchi, D. \& Nagai., M. 2008. A grey-based rough decision-making approach to supplier selection. International Journal of Advanced Manufacturing Technology, 36, pp. 10321040.

[22] Florez-Lopez, R. 2007. Strategic supplier selection in the added-value perspective: $\mathrm{A} \mathrm{Cl}$ approach. Information Sciences, 177(5), pp. 1169-1179.

[23] Aksoy, A. \& Ozturk, N. 2011. Supplier selection and performance evaluation in just-in-time production environments. Expert Systems with Applications, 38, pp. 6351-6359.

[24] Golmohammadi, D. 2011. Neural network application for fuzzy multi-criteria decision making problems. International Journal of Production Economics, 131, pp. 490-504.

[25] Karpak, B., Kumcu, E. \& Kasuganti, R.R. 2001. Purchasing materials in the supply chain: Managing a multi-objective task. European Journal of Purchasing \& Supply Management, 7, pp. 209-216.

[26] Jadidi, O.M.I.D., Zolfaghari, S. \& Cavalieri, S. 2014. A new normalized goal programming model for multi-objective problems: A case of supplier selection and order allocation. International Journal of Production Economics,148, pp. 158-165.

[27] Ghodsypour, S.H. \& O'Brien, C. 2001. The total cost of logistics in supplier selection, under conditions of multiple sourcing, multiple criteria and capacity constraint. International Journal of Production Economics, 73, pp. 15-27.

[28] Talluri, S. 2002. A buyer-seller game model for selection and negotiation of purchasing bids. European Journal of Operational Research, 143, pp. 171-180.

[29] Talluri, S. \& Narasimhan, R. 2003. Vendor evaluation with performance variability: A max-min approach. European Journal of Operational Research, 146, pp. 543-552.

[30] Hong, G.H., Park, S.C., Jang, D.S. \& Rho, H.M. 2005. An effective supplier selection method for constructing a competitive supply-relationship. Expert Systems with Applications, 28(4), pp. 629639.

[31] Ng, W.L. 2008. An efficient and simple model for multiple criteria supplier selection problem. European Journal of Operational Research, 186(3), pp. 1059-1067.

[32] Ware, N.R., Singh, S.P. \& Banwet, D.K. 2014. A mixed-integer non-linear program to model dynamic supplier selection problem. Expert Systems with Applications, 41(2), pp. 671-678.

[33] Narasimhan, R., Talluri, S. \& Mahapatra, S.K. 2006. Multiproduct, multicriteria model for supplier selection with product life-cycle considerations. Decision Sciences, 37(4), pp. 577-603.

[34] Ozkok, B.A. \& Tiryaki, F. 2011. A compensatory fuzzy approach to multi-objective linear supplier selection problem with multiple-item. Expert Systems with Applications, 38, 11363- 
11368

[35] Amin, S.H. \& Zhang, G. 2012. An integrated model for closed-loop supply chain configuration and supplier selection: Multi-objective approach. Expert Systems with Applications, 39(8), p 67826791.

[36] Barla, S.B. 2003. A case study of supplier selection for lean supply by using a mathematical model. Logistics Information Management, 16(6), pp. 451-459.

[37] Choy, K.L., Lee, W.B. \& Lo, V. 2005. A knowledge-based supplier intelligence retrieval system for outsource manufacturing. Knowledge-Based Systems, 18(1), pp. 1-17.

[38] Liao, Z. \& Rittscher, J. 2007. A multi-objective supplier selection model under stochastic demand conditions. International Journal of Production Economics, 105(1), pp. 150-159.

[39] Safa, M., Shahi, A., Haas, C.T. \& Hipel, K.W. 2014. Supplier selection process in an integrated construction materials management model. Automation in Construction, 48, pp. 64-73.

[40] Percin, S. 2006. An application of the integrated AHP-PGP model in supplier selection. Measuring Business Excellence, 10(4), pp. 34-49.

[41] Kull, T.J. \& Talluri, S. 2008. A supply-risk reduction model using integrated multicriteria decision making. IEEE Transactions on Engineering Management, 55(3), pp. 409-419.

[42] Mendoza, A., Santiago, E. \& Ravindran, A.R. 2008. A three-phase multicriteria method to the supplier selection problem. International Journal of Industrial Engineering, 15(2), pp. 195-210.

[43] Yang, C.C. \& Chen, B.S. 2006. Supplier selection using combined analytical hierarchy process and grey relational analysis. Journal of Manufacturing Technology Management, 17(7), pp. 926941.

[44] Ramanathan, R. 2007. Supplier selection problem: Integrating DEA with the approaches of total cost of ownership and AHP. Supply Chain Management: An International Journal, 12(4), pp. 258261.

[45] Sevkli, M., Koh, S.C.L., Zaim, S., Demirbag, M. \& Tatoglu, E. 2007. An application of data envelopment analytic hierarchy process for supplier selection: A case study of BEKO in Turkey. International Journal of Production Research, 45(9), pp. 1973-2003.

[46] Xia, W. \& Wu, Z. 2007. Supplier selection with multiple criteria in volume discount environments. OMEGA - International Journal of Management Science, 35(5), pp. 494-504.

[47] Huang, S.H. \& Keskar, H. 2007. Comprehensive and configurable metrics for supplier selection. International Journal of Production Economics, 105(2), pp. 510-523.

[48] Ha, S.H. \& Krishnan, R. 2008. A hybrid approach to supplier selection for the maintenance of a competitive supply chain. Expert Systems with Applications, 34(2), pp. 1303-1311.

[49] Kokangul, A. \& Susuz, Z. 2009. Integrated analytical hierarch process and mathematical programming to supplier selection problem with quantity discount. Applied Mathematical Modelling, 33, pp. 1417-1429.

[50] Chamodrakas, I., Batis, D. \& Martakos, D. 2010. Supplier selection in electronic marketplaces using satisficing and fuzzy AHP. Expert Systems with Applications, 37, pp. 490-498.

[51] Amid, A., Ghodsypour, S.H. \& O’Brien, C. 2011. A weighted max-min model for fuzzy multiobjective supplier selection in a supply chain. International Journal of Production Economics, 131, pp. 139-145.

[52] Mafakheri, F., Breton, M. \& Ghoniem, A. 2011. Supplier selection-order allocation: A two-stage multiple criteria dynamic programming approach. International Journal of Production Economics, 132, pp. 52-57.

[53] Chen, Y.H. \& Chao, R.J. 2012. Supplier selection using consistent fuzzy preference relations. Expert Systems with Applications, 39(3), pp. 3233-3240.

[54] Rajesh, G. \& Malliga, P. 2013. Supplier selection based on AHP QFD methodology. Procedia Engineering, 64, pp. 1283-1292.

[55] Chen, P. S. \& Wu, M.T. 2013. A modified failure mode and effects analysis method for supplier selection problems in the supply chain risk environment: A case study. Computers \& Industrial Engineering, 66(4), pp. 634-642.

[56] Shyur, H.J. \& Shih, H.S. 2006. A hybrid MCDM model for strategic vendor selection. Mathematical and Computer Modelling, 44, pp. 749-761.

[57] Wu, W.Y., Sukoco, B.M., Li, C.Y. \& Chen, S.H. 2009. An integrated multi-objective decisionmaking process for supplier selection with bundling problem. Expert Systems with Applications, 36, pp. 2327-2337.

[58] Kuo, R.J., Wang, Y.C. \& Tien, F.C. 2010. Integration of artificial neural network and MADA methods for gren supplier selection. Journal of Cleaner Production, 18, pp. 1161-1170.

[59] Chen, C.T., Lin, C.T. \& Huang, S.F. 2006. A fuzzy approach for supplier evaluation and selection in supply chain management. International Journal of Production Economics, 102(2), pp. 289301.

[60] Shahanaghi, K. \& Yazdian, S.A. 2009. Vendor selection using a new fuzzy group TOPSIS approach. Journal of Uncertain Systems, 3(3), pp. 221-231.

[61] Buyukozkan, G. \& Ersoy, M.S. 2009. Applying fuzzy decision making approach to IT outsourcing supplier selection. World Academy Science-Engineering and Technology, 55, pp. 411-415.

[62] Boran, F.E., Genc, S., Kurt, M. \& Akay, D. 2009. A multi-criteria intuitionistic fuzzy group 
decision making for supplier selection with TOPSIS method. Expert Systems with Applications, 36(8), pp. 11363-11368.

[63] Wang, J.V., Cheng, C.H. \& Kun-Cheng, H. 2009. Fuzzy hierarchical TOPSIS for supplier selection. Applied Soft Computing, 9, pp. 377-386.

[64] Awasthi, A., Chauhan, S.S. \& Goyal, S.K. 2010. A fuzzy multicriteria approach for evaluating environmental performance of suppliers. International Journal of Production Economics, 126, pp. 370-378.

[65] Chen, Y.J. 2011. Structured methodology for supplier selection and evaluation in a supply chain. Information Sciences, 181, pp. 1651-1670.

[66] Liao, C.N. \& Kao, H.P. 2011. An integrated fuzzy TOPSIS and MCGP approach to supplier selection in supply chain management. Expert Systems with Applications, 38(9), pp. 1080310811.

[67] Jolai, F., Yazdian, S.A., Shahanaghi, K. \& Khojasteh, M.A. 2011. Integrating fuzzy TOPSIS and multi-period goal programming for purchasing multiple products from multiple suppliers. Journal of Purchasing \& Supply Management, 17, pp. 42-53.

[68] Rouyendegh, B.D. \& Saputro, T.E. 2014. Supplier selection using integrated fuzzy TOPSIS and MCGP: A case study. Procedia-Social and Behavioral Sciences, 116, pp. 3957-3970.

[69] Junior, F.R.L., Osiro, L. \& Carpinetti, L.C.R. 2014. A comparison between fuzzy AHP and fuzzy TOPSIS methods to supplier selection. Applied Soft Computing, 21, pp. 194-209.

[70] Chan, F.T.S. \& Kumar, N. 2007. Global supplier development considering risk factors using fuzzy extended AHP-based approach. OMEGA - International Journal of Management Science, 3(4), pp. 417-431.

[71] Bottani, E. \& Rizzi, A. 2008. An adapted multi-criteria approach to suppliers and products selection - An application oriented to lead-time reduction. International Journal Production Economics, 111(2), pp. 763-781.

[72] Lee, A.H.I. 2009. A fuzzy supplier selection model with the consideration of benefits, opportunities, costs and risks. Expert Systems with Applications, 36, pp. 2879-2893.

[73] Sen, C.G., Sen, S. \& Basligil, H. 2010. Pre-selection of suppliers through an integrated fuzzy analytic hierarchy process and max-min methodology. International Journal of Production Research, 48(6), pp. 1603-1625.

[74] Kilincci, O. \& Onal, S.A. 2011. Fuzzy AHP approach for supplier selection in a washing machine company. Expert Systems with Applications, 38, pp. 9656-9664.

[75] Khorasani, O. \& Bafruei, M.K. 2011. A fuzzy AHP approach for evaluating and selecting supplier in pharmaceutical industry. International Journal of Academic Research, 3(1), pp. 346-352.

[76] Zeydan, M., Colpan, C. \& Cobanoglu, C. 2011. A combined methodology for supplier selection and performance evaluation. Expert Systems with Applications, 38, pp. 2741-2751.

[77] Punniyamoorthy, M., Mathiyalagan, P. \& Parthiban, P. 2011. A strategic model using structural equation modeling and fuzzy logic in supplier selection. Expert Systems with Applications, 38, pp. 458-474.

[78] Kannan, D., Khodaverdi, R., Olfat, L., Jafarian, A. \& Diabat, A. 2013. Integrated fuzzy multi criteria decision making method and multi-objective programming approach for supplier selection and order allocation in a green supply chain. Journal of Cleaner Production, 47, pp. 355-367.

[79] Kar, A.K. 2014. Revisiting the supplier selection problem: An integrated approach for group decision support. Expert systems with applications, 41(6), pp. 2762-2771.

[80] Rezaei, J., Fahim, P.B. \& Tavasszy, L. 2014. Supplier selection in the airline retail industry using a funnel methodology: Conjunctive screening method and fuzzy AHP. Expert Systems with Applications, 41(18), pp. 8165-8179.

[81] Razmi, J., Rafiei, H. \& Hashemi, M. 2009. Designing a decision support system to evaluate and select suppliers using fuzzy analytic network process. Computers \& Industrial Engineering, 57, pp. 1282-1290.

[82] Tuzkaya, G., Ozgen, A., Ozgen, D. \& Tuzkaya, U.R. 2009. Environmental performance evaluation of suppliers: A hybrid fuzzy multi-criteria decision approach. International Journal of Environmental Science and Technology, 6 (3), pp. 477-490.

[83] Onut, S., Kara, S.S. \& Isik, E. 2009. Long term supplier selection using a combined fuzzy MCDM approach: A case study for a telecommunication company. Expert Systems with Applications, 36, pp. 3887-3895.

[84] Wei, J.Y., Sun, A.F. \& Wang, C.H. 2010. The application of fuzzy-ANP in the selection of supplier in supply chain management. International Conference on Logistics Systems and Intelligent Management, pp. 1357-1360.

[85] Vinodh, S., Ramiya, R.A. \& Gautham, S.G. 2011. Application of fuzzy analytic network process for supplier selection in a manufacturing organization. Expert Systems with Applications, 38, pp. 272-280.

[86] Buyukozkan, G. \& Cifci, G. 2011. A novel fuzzymulti-criteria decision framework for sustainable supplier selection with incomplete information. Computers in Industry, 62, pp. 164-174.

[87] Lin, R.H. 2012. An integrated model for supplier selection under a fuzzy situation. International Journal of Production Economics, 138(1), pp. 55-61. 
[88] Dargi, A., Anjomshoae, A., Galankashi, M.R., Memari, A. \& Tap, M.B.M. 2014. Supplier selection: A fuzzy-ANP approach. Procedia Computer Science, 31, pp. 691-700.

[89] Chou, S.Y. \& Chang, Y.H. 2008. A decision support system for supplier selection based on a strategy-aligned fuzzy SMART approach. Expert Systems with Applications, 34(4), pp. 2241-2253.

[90] Bevilacqua, M., Ciarapica, F.E. \& Giacchetta, G. 2006. A fuzzy-QFD approach to supplier selection. Journal of Purchasing and Supply Management, 12(1), pp. 14-27.

[91] Amin, S.H. \& Razmi, J. 2009. An integrated fuzzy model for supplier management: A case study of ISP selection and evaluation. Expert Systems with Applications, 36, pp. 8639-8648.

[92] Keskin, G.A., Ilhan, S. \& Ozkan, C. 2010. The fuzzy ART algorithm: A categorization method for supplier evaluation and selection. Expert Systems with Applications, 37, pp. 1235-1240.

[93] Deng, Y. \& Chan, F.T.S. 2011. A new fuzzy dempster MCDM method and its application in supplier selection. Expert Systems with Applications, 38, pp. 9854-9861.

[94] Wang, Y.M. \& Chin, K.S. 2011. Fuzzy analytic hierarchy process: A logarithmic fuzzy preference programming methodology. International Journal of Approximate Reasoning, 52, pp. 541-553.

[95] Amid, A., Ghodsypour, S.H. \& O’Brien, C. 2006. Fuzzy multiobjective linear model for supplier selection in a supply chain. International Journal of Production Economics, 104(2), pp. 394-407.

[96] Nazari-Shirkouhi, S., Shakouri, H., Javadi, B. \& Keramati, A. 2013. Supplier selection and order allocation problem using a two-phase fuzzy multi-objective linear programming. Applied Mathematical Modelling, 37(22), pp. 9308-9323.

\section{APPENDIX}

\begin{tabular}{|c|c|c|c|c|}
\hline Author(s) & Year & Method(s) & $\begin{array}{l}\text { Sector-based } \\
\text { Application }\end{array}$ & Supplier Selection Criteria \\
\hline Karpak et al. & 2001 & GP & Manufacturing & $\begin{array}{l}\text { Product cost, product quality, delivery } \\
\text { reliability }\end{array}$ \\
\hline $\begin{array}{l}\text { Ghodsypour \& } \\
\text { O’Brien }\end{array}$ & 2001 & $\begin{array}{l}\text { Mixed-integer } \\
\text { non-linear } \\
\text { programming }\end{array}$ & $\begin{array}{l}\text { Hypothetical } \\
\text { example }\end{array}$ & $\begin{array}{l}\text { Price, order cost, timely delivery, capacity, } \\
\text { perfect rate }\end{array}$ \\
\hline $\begin{array}{l}\text { Narasimhan et } \\
\text { al. }\end{array}$ & 2001 & DEA & $\begin{array}{l}\text { Electrical- } \\
\text { electronics }\end{array}$ & $\begin{array}{l}\text { Quality, price, delivery, performance of } \\
\text { decreasing the cost }\end{array}$ \\
\hline Talluri & 2002 & $\begin{array}{l}\text { Binary-integer } \\
\text { linear } \\
\text { programming }\end{array}$ & Health & Price, quality, delivery \\
\hline Sarkis \& Talluri & 2002 & ANP & Manufacturing & $\begin{array}{l}\text { Culture, technology, relation, cost, quality, } \\
\text { time, flexibility }\end{array}$ \\
\hline $\begin{array}{l}\text { Muralidharan } \\
\text { et al. }\end{array}$ & 2002 & AHP & Manufacturing & $\begin{array}{l}\text { Quality, delivery, price, technical skill, } \\
\text { financial condition, previous performance } \\
\text { attitude, factorisation, flexibility, service }\end{array}$ \\
\hline Barla & 2003 & SMART & Manufacturing & $\begin{array}{l}\text { Subcontractor reliability, subcontractor skill, } \\
\text { quality organisation, geographical position, } \\
\text { financial situation, service }\end{array}$ \\
\hline $\begin{array}{l}\text { Talluri \& } \\
\text { Narasimhan }\end{array}$ & 2003 & $\begin{array}{l}\text { Linear } \\
\text { programming }\end{array}$ & Health & $\begin{array}{l}\text { Unit price, timely delivery, rejection, late } \\
\text { delivery }\end{array}$ \\
\hline Chan & 2003 & AHP & $\begin{array}{l}\text { Hypothetical } \\
\text { example }\end{array}$ & Cost, quality, delivery, design \\
\hline Chan \& Chan & 2004 & AHP & $\begin{array}{l}\text { Electrical- } \\
\text { electronics }\end{array}$ & $\begin{array}{l}\text { Cost, delivery, flexibility, innovation, quality, } \\
\text { service }\end{array}$ \\
\hline Choy et al. & 2005 & CBR & Manufacturing & $\begin{array}{l}\text { Price, delivery, quality, innovation level, } \\
\text { technology level, culture, commercial } \\
\text { awareness, production flexibility, ease of } \\
\text { communication }\end{array}$ \\
\hline Liu \& Hai & 2005 & AHP & $\begin{array}{l}\text { Furniture white } \\
\text { goods }\end{array}$ & $\begin{array}{l}\text { Quality, responsibility, discipline, delivery, } \\
\text { financial management, technical skill }\end{array}$ \\
\hline Hong et al. & 2005 & $\begin{array}{l}\text { Mixed-integer } \\
\text { linear } \\
\text { programming }\end{array}$ & $\begin{array}{l}\text { Agriculture- } \\
\text { construction }\end{array}$ & $\begin{array}{l}\text { Number of the purchased goods, quality, price, } \\
\text { amount }\end{array}$ \\
\hline
\end{tabular}




\begin{tabular}{|c|c|c|c|c|}
\hline $\begin{array}{l}\text { Bevilacqua } \\
\text { et al. }\end{array}$ & 2006 & Fuzzy QFD & Automotive & $\begin{array}{l}\text { Sector experience, quality system certificate, } \\
\text { flexibility of respond to customer demands, financial } \\
\text { determination, geographical position, skill of } \\
\text { managing the online orders }\end{array}$ \\
\hline Amid et al. & 2006 & Fuzzy MOP & $\begin{array}{l}\text { Hypothetical } \\
\text { example }\end{array}$ & Cost, quality, service, capacity \\
\hline Yang \& Chen & 2006 & AHP - GRA & $\begin{array}{l}\text { Electrical- } \\
\text { electronics }\end{array}$ & $\begin{array}{l}\text { Quality, finance, customer service, production } \\
\text { capacity, design technical skill, system of } \\
\text { information technologies, capital turnover, cost, } \\
\text { delivery }\end{array}$ \\
\hline Percin & 2006 & AHP - GP & Automotive & $\begin{array}{l}\text { Production skill, convenience quality, flexibility, } \\
\text { delivery reliability, constant development programs, } \\
\text { technical information sharing, technological } \\
\text { coherence, skill of product innovation, } \\
\text { organisational structure, publicity and position in the } \\
\text { industry, financial power, management skills, } \\
\text { performance background, geographical position, } \\
\text { long-term relation, respond to complaints, } \\
\text { communication systems, guarantee support, } \\
\text { restoration and maintenance service }\end{array}$ \\
\hline Bayazit & 2006 & ANP & $\begin{array}{l}\text { Hypothetical } \\
\text { example }\end{array}$ & $\begin{array}{l}\text { Flexibility, timely delivery, price, delivery time, } \\
\text { quality, market share, staff skill, process skill, senior } \\
\text { management skill, financial skill }\end{array}$ \\
\hline $\begin{array}{l}\text { Narasimhan } \\
\text { et al. }\end{array}$ & 2006 & MOP & $\begin{array}{l}\text { Electrical- } \\
\text { electronics }\end{array}$ & $\begin{array}{l}\text { Direct cost, indirect coordination cost, quality, } \\
\text { delivery reliability }\end{array}$ \\
\hline Hou \& Su & 2006 & AHP & $\begin{array}{l}\text { Electrical- } \\
\text { electronics }\end{array}$ & $\begin{array}{l}\text { Quality, cost, technology, production skill, research } \\
\text { development, delivery, geographical position, } \\
\text { performance and service }\end{array}$ \\
\hline Chen et al. & 2006 & Fuzzy TOPSIS & Manufacturing & $\begin{array}{l}\text { Profit of the supplier, relation imminence, } \\
\text { technological skill, quality, problem solving }\end{array}$ \\
\hline Shyur \& Shih & 2006 & ANP - TOPSIS & $\begin{array}{l}\text { Hypothetical } \\
\text { example }\end{array}$ & $\begin{array}{l}\text { Timely delivery, product quality, cost, respond to } \\
\text { the needs of customers, professionalism of the } \\
\text { salesperson, quality of the relation with suppliers, } \\
\text { technology }\end{array}$ \\
\hline $\begin{array}{l}\text { Liao \& } \\
\text { Rittscher }\end{array}$ & 2007 & GA & $\begin{array}{l}\text { Hypothetical } \\
\text { example }\end{array}$ & Cost, quality, delivery, flexibility \\
\hline Xia \& Wu & 2007 & $\begin{array}{l}\text { AHP-multi- } \\
\text { objective } \\
\text { mixed-integer } \\
\text { programming }\end{array}$ & $\begin{array}{l}\text { Hypothetical } \\
\text { example }\end{array}$ & $\begin{array}{l}\text { Price, quality (technical level, mistakes, reliability), } \\
\text { service (timely delivery, supply capacity, time for } \\
\text { restoration alternation, guarantee period) }\end{array}$ \\
\hline Sevkli et al. & 2007 & AHP - DEA & $\begin{array}{l}\text { Furniture white } \\
\text { goods }\end{array}$ & $\begin{array}{l}\text { Transportation quality, delivery, cost, number of } \\
\text { employees, organisational structure, education, } \\
\text { number of technical staff, management } \\
\text { commitment, quality planning, storage, } \\
\text { development, publicity, imminence, price, patent, } \\
\text { technical skill }\end{array}$ \\
\hline Ramanathan & 2007 & AHP - DEA & $\begin{array}{l}\text { Hypothetical } \\
\text { example }\end{array}$ & $\begin{array}{l}\text { Production costs, quality, technology, post-sales } \\
\text { service }\end{array}$ \\
\hline $\begin{array}{l}\text { Huang \& } \\
\text { Keskar }\end{array}$ & 2007 & AHP - MAUT & $\begin{array}{l}\text { Electrical- } \\
\text { electronics }\end{array}$ & $\begin{array}{l}\text { Reliability, respond to needs, flexibility, cost and } \\
\text { finance, infrastructure and existence, security, } \\
\text { environment }\end{array}$ \\
\hline $\begin{array}{l}\text { Florez- } \\
\text { Lopez }\end{array}$ & 2007 & SOFM & $\begin{array}{l}\text { Hypothetical } \\
\text { example }\end{array}$ & $\begin{array}{l}\text { Efforts of decreasing the cost, delivery delays, price, } \\
\text { reliability, quality, respond to needs, commitment } \\
\text { for development, delivery mistakes, fluctuation in } \\
\text { the cost, order mistakes, timely communication, } \\
\text { customer service, technical support }\end{array}$ \\
\hline Chan et al. & 2007 & AHP & $\begin{array}{l}\text { Transportation- } \\
\text { logistics }\end{array}$ & $\begin{array}{l}\text { Cost, supplier's satisfaction, quality, research- } \\
\text { development, organisational culture, compatibility, } \\
\text { realisation of the risk, security, environmental and } \\
\text { educational issues, technological issue, financial } \\
\text { issue }\end{array}$ \\
\hline
\end{tabular}




\begin{tabular}{|c|c|c|c|c|}
\hline $\begin{array}{l}\text { Gencer \& } \\
\text { Gurpınar }\end{array}$ & 2007 & ANP & $\begin{array}{l}\text { Electrical- } \\
\text { electronics }\end{array}$ & $\begin{array}{l}\text { General knowledge of the supplier, organisational } \\
\text { profile of the supplier, financial situation of the } \\
\text { supplier, equipment status of the supplier, } \\
\text { production skill of the supplier, material handling } \\
\text { skill of the supplier, quality system certificate of the } \\
\text { supplier, quality system documentation of the } \\
\text { supplier }\end{array}$ \\
\hline $\begin{array}{l}\text { Chan \& } \\
\text { Kumar }\end{array}$ & 2007 & $\begin{array}{l}\text { Fuzzy extended } \\
\text { AHP }\end{array}$ & Manufacturing & $\begin{array}{l}\text { Total cost of the product, product quality, service } \\
\text { performance of the supplier, profile of the supplier, } \\
\text { risk factor }\end{array}$ \\
\hline $\begin{array}{l}\text { Chou \& } \\
\text { Chang }\end{array}$ & 2008 & Fuzzy SMART & Informatics & $\begin{array}{l}\text { Cost, quality, delivery, organisational culture and } \\
\text { strategy, technical capacity }\end{array}$ \\
\hline $\begin{array}{l}\text { Ha \& } \\
\text { Krishnan }\end{array}$ & 2008 & AHP - DEA - ANN & Manufacturing & $\begin{array}{l}\text { Production accessibility, intent of the quality } \\
\text { management, outputs of the quality system, quality } \\
\text { recruitment, respond to demands, timely delivery, } \\
\text { organisational control, work plans, customer } \\
\text { relations, internal control, data management }\end{array}$ \\
\hline $\mathrm{Ng}$ & 2008 & Linear & Agriculture- & Supply diversity, quality, distance, delivery, price \\
\hline $\begin{array}{l}\text { Bottani \& } \\
\text { Rizzi }\end{array}$ & 2008 & $\begin{array}{l}\text { Fuzzy AHP - } \\
\text { Cluster analysis }\end{array}$ & Manufacturing & $\begin{array}{l}\text { Customer satisfaction, technical and organisational } \\
\text { skills, willingness of the supplier, interest of the } \\
\text { supplier, economic value, amount of the annual } \\
\text { order, waiting period }\end{array}$ \\
\hline Kull \& Talluri & 2008 & AHP - GP & Automotive & $\begin{array}{l}\text { Risk value, delivery, cost, quality, flexibility, } \\
\text { general reliance }\end{array}$ \\
\hline Li et al. & 2008 & GRA & $\begin{array}{l}\text { Hypothetical } \\
\text { example }\end{array}$ & Product quality, service, delivery, price \\
\hline $\begin{array}{l}\text { Mendoza et } \\
\text { al. }\end{array}$ & 2008 & AHP - GP & $\begin{array}{l}\text { Hypothetical } \\
\text { example }\end{array}$ & Flexibility, quality, price, service, delivery \\
\hline Boran et al. & 2009 & Fuzzy TOPSIS & Automotive & $\begin{array}{l}\text { Product quality, relation imminence, delivery } \\
\text { performance, price }\end{array}$ \\
\hline $\begin{array}{l}\text { Amin \& } \\
\text { Razmi }\end{array}$ & 2009 & Fuzzy QFD & Informatics & $\begin{array}{l}\text { Accessibility, reliability, security, speed, effective } \\
\text { marketing and promotion, experience, financial } \\
\text { power, management resolution, strategically } \\
\text { association, support source, monthly salary, set-up } \\
\text { fee, supply diversity }\end{array}$ \\
\hline Razmi et al. & 2009 & Fuzzy ANP & $\begin{array}{l}\text { Hypothetical } \\
\text { example }\end{array}$ & $\begin{array}{l}\text { Quality, end time, degree of the company, } \\
\text { background of the company, economic condition of } \\
\text { the company, price }\end{array}$ \\
\hline Lee & 2009 & Fuzzy AHP & $\begin{array}{l}\text { Electrical- } \\
\text { electronics }\end{array}$ & $\begin{array}{l}\text { Flexibility, quality, delivery, common growth, } \\
\text { supplier's technology, relation structure, relation } \\
\text { cost_. product cost._supolv restriction }\end{array}$ \\
\hline $\begin{array}{l}\text { Buyukozkan } \\
\text { \& Ersoy }\end{array}$ & 2009 & Fuzzy TOPSIS & Informatics & $\begin{array}{l}\text { Technological skill, supplier's profit, relation } \\
\text { imminence, total cost, service quality, publicity of } \\
\text { the supplier }\end{array}$ \\
\hline Wang et al. & 2009 & $\begin{array}{l}\text { Fuzzy } \\
\text { hierarchical } \\
\text { TOPSIS }\end{array}$ & $\begin{array}{l}\text { Hypothetical } \\
\text { example }\end{array}$ & Cost, key quality characteristics, service \\
\hline $\begin{array}{l}\text { Kokangul \& } \\
\text { Susuz }\end{array}$ & 2009 & $\begin{array}{l}\text { AHP - Non- } \\
\text { linear integer }\end{array}$ & Automotive & $\begin{array}{l}\text { Price performance, delivery performance, } \\
\text { cooperation and development performance, quality }\end{array}$ \\
\hline Wu et al. & 2009 & $\begin{array}{l}\text { ANP - Mixed- } \\
\text { integer } \\
\text { programming }\end{array}$ & $\begin{array}{l}\text { Electrical- } \\
\text { electronics }\end{array}$ & $\begin{array}{l}\text { Management quality, technical quality, operational } \\
\text { quality, fixed cost, variable cost }\end{array}$ \\
\hline Onut et al. & 2009 & $\begin{array}{l}\text { Fuzzy ANP - } \\
\text { Fuzzy TOPSIS }\end{array}$ & $\begin{array}{l}\text { Electrical- } \\
\text { electronics }\end{array}$ & $\begin{array}{l}\text { Cost, references, product quality, delivery time, } \\
\text { institutionalism, application time }\end{array}$ \\
\hline $\begin{array}{l}\text { Shahanaghi } \\
\text { \& Yazdian }\end{array}$ & 2009 & $\begin{array}{l}\text { Fuzzy Group } \\
\text { TOPSIS }\end{array}$ & Automotive & Cost, performance, quality \\
\hline $\begin{array}{l}\text { Tuzkaya et } \\
\text { al. }\end{array}$ & 2009 & $\begin{array}{l}\text { Fuzzy ANP - } \\
\text { Fuzzy } \\
\text { PROMETHEE }\end{array}$ & $\begin{array}{l}\text { Furniture } \\
\text { white goods }\end{array}$ & $\begin{array}{l}\text { Environmental process management, pollution } \\
\text { control, environmental and legal management, } \\
\text { environmental costs, environmental image, } \\
\text { environmental product. }\end{array}$ \\
\hline Kuo et al. & 2010 & ANN - ANP - DEA & $\begin{array}{l}\text { Electrical- } \\
\text { electronics }\end{array}$ & $\begin{array}{l}\text { Quality, cost, delivery, service, environment, } \\
\text { common social Responsibility }\end{array}$ \\
\hline
\end{tabular}




\begin{tabular}{|c|c|c|c|c|}
\hline $\begin{array}{l}\text { Keskin et } \\
\text { al. }\end{array}$ & 2010 & Fuzzy ART & Automotive & $\begin{array}{l}\text { Production security, similar items that are } \\
\text { produced, technical efficiency of employee and } \\
\text { equipment, efficiency of the production capacity, } \\
\text { available testing skill, skill of design and } \\
\text { recruitment, raw material, financial skill for } \\
\text { finding end products and other resources, price } \\
\text { politics and convenience of payment periods, } \\
\text { effective use of certificates, packaging, } \\
\text { transportation and skill of logistic requirement, } \\
\text { geographical position, job security and applications } \\
\text { of worker health, environmental effects and }\end{array}$ \\
\hline $\begin{array}{l}\text { Awasthi et } \\
\text { al. }\end{array}$ & 2010 & Fuzzy TOPSIS & $\begin{array}{l}\text { Hypothetical } \\
\text { example }\end{array}$ & $\begin{array}{l}\text { Use of eco-friendly technology, use of eco-friendly } \\
\text { material, market share of environmentalism, } \\
\text { cooperation with environmental organisations, } \\
\text { management commitment, commitment to } \\
\text { environmental politics, eco-friendly research and } \\
\text { development projects, employee training, simple } \\
\text { process planning, design for the environment, } \\
\text { environmental certification, control initiatives for } \\
\text { pollution }\end{array}$ \\
\hline $\begin{array}{l}\text { Chamodrak } \\
\text { as et al. }\end{array}$ & 2010 & $\begin{array}{l}\text { AHP-based fuzzy } \\
\text { preference }\end{array}$ & $\begin{array}{l}\text { Hypothetical } \\
\text { example }\end{array}$ & Quality, cost, delivery \\
\hline Wei et al. & 2010 & Fuzzy ANP & $\begin{array}{l}\text { Hypothetical } \\
\text { example }\end{array}$ & Quality, service, reliability, cost \\
\hline Liao et al. & 2010 & ANP & $\begin{array}{l}\text { Electrical- } \\
\text { electronics }\end{array}$ & $\begin{array}{l}\text { Performance (quality, timely marketability), } \\
\text { feedback (esteem, rate, finance), interaction } \\
\text { (relation, behaviour, communication), production } \\
\text { (creativity, price, time) }\end{array}$ \\
\hline Sen et al. & 2010 & $\begin{array}{l}\text { Fuzzy AHP - } \\
\text { Max-min } \\
\text { abproach }\end{array}$ & $\begin{array}{l}\text { Electrical- } \\
\text { electronics }\end{array}$ & Cost, quality, service, reliability \\
\hline Chen & 2011 & $\begin{array}{l}\text { DEA - Fuzzy } \\
\text { TOPSIS }\end{array}$ & Textile & $\begin{array}{l}\text { Quality, technology a production, cost, } \\
\text { organisational Management }\end{array}$ \\
\hline Liao \& Kao & 2011 & $\begin{array}{l}\text { Fuzzy TOPSIS - } \\
\text { GP }\end{array}$ & $\begin{array}{l}\text { Electrical- } \\
\text { electronics }\end{array}$ & $\begin{array}{l}\text { Relation imminence, product quality, delivery skill, } \\
\text { guarantee level, experiment process }\end{array}$ \\
\hline $\begin{array}{l}\text { Buyukozkan } \\
\text { \& Ciftci }\end{array}$ & 2011 & Fuzzy ANP & $\begin{array}{l}\text { Furniture white } \\
\text { goods }\end{array}$ & Time, cost, quality, flexibility \\
\hline $\begin{array}{l}\text { Vinodh et } \\
\text { al. }\end{array}$ & 2011 & Fuzzy ANP & $\begin{array}{l}\text { Electrical- } \\
\text { electronics }\end{array}$ & $\begin{array}{l}\text { Work enhancement, convenience dimension, } \\
\text { quality, service, risks }\end{array}$ \\
\hline Jolai et al. & 2011 & $\begin{array}{l}\text { Fuzzy TOPSIS - } \\
\text { GP }\end{array}$ & Automotive & $\begin{array}{l}\text { Timely delivery, imminence of relations with } \\
\text { suppliers, product quality of the supplier, } \\
\text { technological skill of the supplier, price/cost }\end{array}$ \\
\hline $\begin{array}{l}\text { Aksoy \& } \\
\text { Ozturk }\end{array}$ & 2011 & ANN & Automotive & $\begin{array}{l}\text { Quality, timely delivery performance, geographical } \\
\text { position, price }\end{array}$ \\
\hline $\begin{array}{l}\text { Zeydan et } \\
\text { al. }\end{array}$ & 2011 & $\begin{array}{l}\text { Fuzzy AHP - } \\
\text { Fuzzy TOPSIS } \\
\text { DEA }\end{array}$ & Automotive & $\begin{array}{l}\text { New project management, supplier improvement, } \\
\text { quality and environmental management, test and } \\
\text { supervising management, management of } \\
\text { restoration and prevention activities, production } \\
\text { process management }\end{array}$ \\
\hline $\begin{array}{l}\text { Wang \& } \\
\text { Chin }\end{array}$ & 2011 & $\begin{array}{l}\text { Fuzzy } \\
\text { preference } \\
\text { programming }\end{array}$ & $\begin{array}{l}\text { Transportation- } \\
\text { logistics }\end{array}$ & $\begin{array}{l}\text { Economic factors, social factors, political } \\
\text { conditions }\end{array}$ \\
\hline $\begin{array}{l}\text { Golmoham } \\
\text { madi }\end{array}$ & 2011 & ANN & Automotive & $\begin{array}{l}\text { Quality, delivery, technology, price, geographical } \\
\text { position }\end{array}$ \\
\hline Amid et al. & 2011 & $\begin{array}{l}\text { AHP - Max-min } \\
\text { fuzzy } \\
\text { programming }\end{array}$ & $\begin{array}{l}\text { Hypothetical } \\
\text { example }\end{array}$ & Quality, net cost, service \\
\hline $\begin{array}{l}\text { Ozkok \& } \\
\text { Tiryaki }\end{array}$ & 2011 & $\begin{array}{l}\text { Multi-objective } \\
\text { linear supplier } \\
\text { selection } \\
\text { problem with } \\
\text { multiple-item }\end{array}$ & Textile & $\begin{array}{l}\text { Price, quality level, service quality level, upper } \\
\text { limit of item quantity to be obtained from } \\
\text { suppliers, upper limit of the rejected item quantity }\end{array}$ \\
\hline $\begin{array}{l}\text { Deng \& } \\
\text { Chan }\end{array}$ & 2011 & FST - DST & $\begin{array}{l}\text { Hypothetical } \\
\text { example }\end{array}$ & $\begin{array}{l}\text { Late product delivery, cost, risk factor, service } \\
\text { performance }\end{array}$ \\
\hline
\end{tabular}




\begin{tabular}{|c|c|c|c|c|}
\hline $\begin{array}{l}\text { Punniyamo } \\
\text { orth et al. }\end{array}$ & 2011 & $\begin{array}{l}\text { Structural } \\
\text { Equation } \\
\text { Modelling - } \\
\text { Fuzzy AHP }\end{array}$ & Manufacturing & $\begin{array}{l}\text { Management and organisation, quality, technical } \\
\text { skill, conveniences and capacities of production, } \\
\text { financial situation, distribution, service, relations, } \\
\text { issues of security and environment, cost }\end{array}$ \\
\hline $\begin{array}{l}\text { Khorasani \& } \\
\text { Bafruei }\end{array}$ & 2011 & Fuzzy AHP & Health & Price, quality, service, organisation, technics \\
\hline $\begin{array}{l}\text { Mahdiloo et } \\
\text { al. }\end{array}$ & 2011 & DEA & $\begin{array}{l}\text { Hypothetical } \\
\text { example }\end{array}$ & $\begin{array}{l}\text { Total cost of transportations, number of monthly } \\
\text { shipping, research-development costs, number of } \\
\text { timely transportations, number of bills that are } \\
\text { received from suppliers without mistake }\end{array}$ \\
\hline $\begin{array}{l}\text { Kilincci \& } \\
\text { Onal }\end{array}$ & 2011 & Fuzzy AHP & $\begin{array}{l}\text { Furniture white } \\
\text { goods }\end{array}$ & $\begin{array}{l}\text { Supplier criteria (financial status, management, } \\
\text { technical skill, quality systems, geographical } \\
\text { condition, working with kanban approach), } \\
\text { criteria of product performance (product price, } \\
\text { packaging, product quality), criteria of service } \\
\text { performance (delay time, technical support, } \\
\text { professionalisation, follow-up) }\end{array}$ \\
\hline $\begin{array}{l}\text { Mafakheri } \\
\text { et al. }\end{array}$ & 2011 & $\begin{array}{l}\text { AHP - Dynamic } \\
\text { programming }\end{array}$ & $\begin{array}{l}\text { Hypothetical } \\
\text { example }\end{array}$ & $\begin{array}{l}\text { Price performance, delivery performance, } \\
\text { environmental performance, quality }\end{array}$ \\
\hline $\begin{array}{l}\text { Asamoah et } \\
\text { al }\end{array}$ & 2012 & AHP & Health & Quality, price, reliability/capacity \\
\hline Lin & 2012 & $\begin{array}{l}\text { Fuzzy ANP - } \\
\text { Fuzzy MOLP }\end{array}$ & $\begin{array}{l}\text { Hypothetical } \\
\text { example }\end{array}$ & Price, quality, delivery, technique \\
\hline $\begin{array}{l}\text { Chen \& } \\
\text { Chao }\end{array}$ & 2012 & $\begin{array}{l}\text { AHP - Consistent } \\
\text { Fuzzy }\end{array}$ & $\begin{array}{l}\text { Electrical- } \\
\text { electronics }\end{array}$ & $\begin{array}{l}\text { Suppliers general, price and delivery, quality, } \\
\text { professional techniques conditions }\end{array}$ \\
\hline $\begin{array}{l}\text { Amin \& } \\
\text { Zhang }\end{array}$ & 2012 & $\begin{array}{l}\text { Multi-objective } \\
\text { mixed-integer } \\
\text { linear } \\
\text { programming }\end{array}$ & $\begin{array}{l}\text { Electrical- } \\
\text { electronics }\end{array}$ & $\begin{array}{l}\text { Cost, delivery, experience, quality, part safety, } \\
\text { lightweight, recyclable, process capability, design } \\
\text { process, reduction of wastes, using clean } \\
\text { technology }\end{array}$ \\
\hline Bruno et al. & 2012 & AHP & $\begin{array}{l}\text { Transportation- } \\
\text { logistics }\end{array}$ & $\begin{array}{l}\text { Process and product quality, service level, } \\
\text { management and innovation, financial position }\end{array}$ \\
\hline $\begin{array}{l}\text { Kannan et } \\
\text { al. }\end{array}$ & 2013 & $\begin{array}{l}\text { Fuzzy AHP - } \\
\text { Fuzzy TOPSIS - }\end{array}$ & Automotive & $\begin{array}{l}\text { Cost, quality, delivery, technology capability, } \\
\text { environmental competency }\end{array}$ \\
\hline $\begin{array}{l}\text { Rajesh \& } \\
\text { Malliga }\end{array}$ & 2013 & AHP-QFD & Manufacturing & Quality, cost, delivery \\
\hline $\begin{array}{l}\text { Nazari- } \\
\text { Shirkouhi }\end{array}$ & 2013 & $\begin{array}{l}\text { Fuzzy Multi- } \\
\text { Objective Linear }\end{array}$ & $\begin{array}{l}\text { Hypothetical } \\
\text { example }\end{array}$ & $\begin{array}{l}\text { A number of defective units, and late delivered } \\
\text { units }\end{array}$ \\
\hline Chen \& Wu & 2013 & $\begin{array}{l}\text { Modified Failure } \\
\text { Mode And }\end{array}$ & $\begin{array}{l}\text { Electrical- } \\
\text { electronics }\end{array}$ & $\begin{array}{l}\text { Cost, quality, deliverability, technology, } \\
\text { productivity, service }\end{array}$ \\
\hline $\begin{array}{l}\text { Rouyendeg } \\
\text { h et al. }\end{array}$ & 2014 & $\begin{array}{l}\text { Fuzzy TOPSIS - } \\
\text { Multi-Choice GP }\end{array}$ & $\begin{array}{l}\text { Agriculture- } \\
\text { construction }\end{array}$ & $\begin{array}{l}\text { Supply capacity, production, capacity, response } \\
\text { time, production technology, price, warranty, } \\
\text { procedural compliance, purchase transaction, } \\
\text { communication system, quality, completed } \\
\text { shipping document, quantity, on time delivery, } \\
\text { financial position, location, reputation, }\end{array}$ \\
\hline Ware et al. & 2014 & $\begin{array}{l}\text { Mixed-Integer } \\
\text { Non-Linear } \\
\text { Program (MINLP) }\end{array}$ & $\begin{array}{l}\text { Hypothetical } \\
\text { example }\end{array}$ & $\begin{array}{l}\text { Generated data for supplier's capacity, } \\
\text { organisation's demand for each part for both } \\
\text { periods, unit part cost for each suppliers, fixed } \\
\text { transportation cost, quality level of all parts for } \\
\text { each suppliers in each period, unit penalty cost } \\
\text { incurred, late delivery, unit delay cost incurred, } \\
\text { data of all suppliers for all parts }\end{array}$ \\
\hline Kar & 2014 & AHP-Fuzzy GP & Manufacturing & $\begin{array}{l}\text { Product, delivery compliance, price, technological } \\
\text { capability, production capability, financial } \\
\text { position, e-transaction capability, consistency } \\
\text { measures, consensus index }\end{array}$ \\
\hline $\begin{array}{l}\text { Rezaei et } \\
\text { al. }\end{array}$ & 2014 & Fuzzy AHP & $\begin{array}{l}\text { Transportation- } \\
\text { logistics }\end{array}$ & $\begin{array}{l}\text { Cost/price, product quality, delivery, financial } \\
\text { stability, assortment, corporate social }\end{array}$ \\
\hline Jadidi et al. & 2014 & $\begin{array}{l}\text { Multi-Objective } \\
\text { Optimization }\end{array}$ & $\begin{array}{l}\text { Hypothetical } \\
\text { example }\end{array}$ & Supplier capacity, price, defect rate, late delivery \\
\hline $\begin{array}{l}\text { Junior et } \\
\text { al. }\end{array}$ & 2014 & $\begin{array}{l}\text { Fuzzy TOPSIS- } \\
\text { Fuzzy AHP }\end{array}$ & Automotive & $\begin{array}{l}\text { Quality, price, delivery, supplier profile, supplier } \\
\text { relationship }\end{array}$ \\
\hline Dargi et al. & 2014 & Fuzzy ANP & Automotive & $\begin{array}{l}\text { Quality, price, production capacity, technical } \\
\text { capability\& facility, service \& delivery, reputation, }\end{array}$ \\
\hline $\begin{array}{l}\text { Dobö \& } \\
\text { Vörösmarty }\end{array}$ & 2014 & DEA & $\begin{array}{l}\text { Hypothetical } \\
\text { example }\end{array}$ & Lead time, quality, price, reusability, $\mathrm{CO}_{2}$ emission \\
\hline Safa et al. & 2014 & TOPSIS & $\begin{array}{l}\text { Agriculture- } \\
\text { construction }\end{array}$ & Price, lead time, performance, early payment \\
\hline
\end{tabular}

